International Journal of Scholarly Papers for Media and Communications

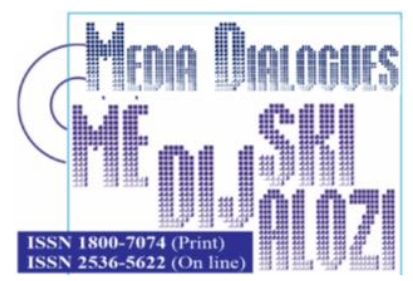

Vukanovic, Z. (2020), „New Paradigm Models in Digital Media Business (IP TV and Mobile TV)",Media Dialogues / Medijski dijalozi, Vol. 13, No. 3, pp. 7-24.

\title{
New Paradigm Models in Digital Media Business (IP TV and Mobile TV)
}

\section{PhD ZVEZDAN VUKANOVIC,}

University of Donja Gorica, Faculty of International Economics, Finance and Business, Faculty of Information Systems and Technology,

Podgorica, Montenegro

\begin{tabular}{|c|c|}
\hline $\boldsymbol{A} \boldsymbol{R} \boldsymbol{T} \boldsymbol{I} \boldsymbol{C L} \boldsymbol{E}$ & Received: November12,2019 / Revised from: December 12, 2019 \\
I N F O & Accepted: January 12,2020 / Available online: July 15, 2020 \\
\hline DOI & doi.org/10.14254/1800-7074/13-3/1 \\
\hline
\end{tabular}

\begin{abstract}
The purpose of this article is to analyze the role of the economies of aggregation in new and digital media (IP TV and Mobile TV) business. The author argues it is necessary for international corporations to provide a holistic response that regards economics as a set of mutually interactive aggregate segment in order to position global media industry and businesses in highly competitive and volatile markets. Therefore, the article proposes the creation and adoption of four strategic approaches in emphasizing the economies of aggregation: the Triple- and Quadruple-Play Bundling Strategies, Two-Sided markets, Complementors and Network Externali-ties. Adding and implementing these complex microeconomic approaches will result in accelerating and increasing the competitiveness and innovation, market share, de-mand, profit of global media companies. The author
\end{abstract}


empirically prves the validity for IPTV and Mobile TV market growth by calculating the projected number of worl-dwide users from 2009 to 2015 based on the analysis of nineteen leading internati-onal research and consulting agencies. The figures show an increase of Mobile TV subscribers from 2009 to 2015 for approximately $242 \%$ (78.5 to 190 millions). On the other hand, the research shows an 44 increase of IPTV subscribers from 2009 to 2013 for 202\% (42.2 to 85.5 millions). In conclusion, it is important to realize that the greatest potential for the application of the economies of aggregation in the global media industry is evident in the emerging global IP TV and Mobile TV markets. The reason is that only $1.8 \%$ of all mobile phone users worldwide that are presently esti-mated at 3.3 billion are Mobile TV subscribers, whereas only $2.2 \%$ of all TV users worldwide (currently estimated at 1 billion) are IPTV subscribers.

KEYWORDS: Digital media, interactive media, communications, media economics, multihoming, IP TV, cellular-mobile TV.

\section{INTRODUCTION}

Due to the increasing global competition economists generally agree that an important feature of any modern macroeconomic theory is an explicit aggregation of the microeconomic behavior of all agents in the economy. During the last two decades, user-generated content, mass customization, and personalization have replaced mass production in the media business. Accordingly, economies of scale have been substituted largely by economies of scope. Meanwhile, global hyper-competition has fragmented niche markets and stimulated media corporations to search for more original and innovative services. To be profitable, innovative services in the media industry and business have to be diffused and distributed efficiently and effectively via various cross-media platforms (broadband, multicast, and convergent digital models). Ideally, the economies of aggregation can be based on four crucial strategic and economic concepts: Triple- and Quadruple-Play Bundling Strategies, Two-Sided markets, Complementors and Network Externalities. It is important to point out that all four concepts are fundamental in terms of increasing the demand and diffusion of innovation.

\section{MAJOR MODELS OF DIFFUSION OF INNOVATIONS}

To be profitable and effectively applied by consumers, the innovation has to be efficiently diffused. This notion implies that innovation is of little value unless it diffuses. Effective diffusion of innovations increases economies of scale effects and captures profits before competitors. The diffusion of innovation is particularly impor- tant in media industry, as the global competition tends to be fierce, whereas the market is becoming increasingly volatile. Generally speaking, companies should 
accelerate the diffusion of innovations because early movers tend to achieve higher market shares.

The major models of innovation management and its diffusion models that have been recommended by experts at the beginning of the 21 st century include:

- Sustained innovation (Trauffler and Tschirky, 2007),

- Hyperinnovation (Harris, C. and Harris, C.M., 2002)

- Incremental innovation (Trauffler and Tschirky, 2007),

- Persistent Innovation (Le Bas and Latham, 2005),

- Open innovation (Vanhaverbeke et al., 2006), and

- Innovation by demand (McMeekin, et al., 2002).

Accordingly, it is advisable to point that main trends of effective and profitable innovation and its diffusion models will have to display characteristics that are related to efficient, sustained, incremental and persistent innovation that is based by consumer and business demands.

\section{THE ECONOMIES OF AGGREGATION IN GLOBAL MEDIA BUSINESS}

Furthermore, the importance of the economies of aggregation in global media business is particularly important as present and future markets are in the process of global expansion. The potential for global competition will increase by about $300 \%$ between 2007 and 2037. It is important to notice that in terms of the average return on invested capital, the media industry (1963-2003), together with pharmaceuticals, hou- sehold and personal products, and computer software and services, represents the most profitable global industry (Grant, 2008).

The increased importance of the media industry has grown incessantly over the last 15 years as a result of a continual deregulation of broadcasting industries as well as new digital convergence. Its increased importance is particularly reflected in economic respects. The global media industry encompasses over $\$ 1$ trillion (Vizjak and Ringlstetter, 2003) and accounted for about $22 \%$ of the total information industries' revenue (Compaine and Gomery, 2000). In its annual media forecast, Pricewaterhouse-Coopers (2008) projects that global media revenue will grow by an average of $6.6 \%$ per year, reaching $\$ 1.29$ trillion in 2012 .

Neoliberal globalization will accelerate network (effects) externalities. Studies by Barrett and Yang (2001), Economides (1996a, 1996b), Katz and Shapiro (1994), Kikuchi and Kobayashi (2007), and Shy (2001) demonstrated that the role and impact of network effects is amplified in the globalized world and trade liberalization (Barrett and Yang, 2001; Economides, 1996, 1996a; Katz and Shapiro, 1994; Kikuchi and Kobayashi, 2007; Shy, 2001). Furthermore, international firms gain from 
globalization and trade liberalization due to intensified network effects (Kikuchi and Kobayashi, 2007).

\section{EMPIRICAL EVIDENCE FOR GLOBAL GROWTH OF MOBILE TV AND IPTV MARKETS}

The author empirically proves the validity for IPTV and Mobile TV market growth by calculating the projected number of worldwide users from 2009 to 2015 based on the analysis of nineteen leading international research and consulting agencies dominantly based in the USA, UK, China and India. The international consulting agencies that calculate the projected number of worldwide users of Mobile TV in the period 2009 - 2015 include In Stat Research, Datamonitor Research, Inofonetics Research, RNCOS, Informa Telecoms and Media, Juniper Research and McKinsey Research. Their projections of worldwide Mobile TV users show an increase of Mobile TV subscribers from 2009 to 2015 for approximately 242\% (78.5 to 190 millions).

On the other hand, the research covering the projection of worldwide IP TV subscribers was based on the reports of the following international consulting agencies MRG - Multimedia Research Group, Gartner Research, Infonetics Research, Strategy Analytics, Open IPTV Forum, IMS research, Parks and Associates, i Supply Corporation, RNCOS, Pyramid Research, Canalys, Companies and Markets. Their research shows an increase of IPTV subscribers from 2009 to 2013 for 202\% (42.2 to 85.5 millions).

\section{TRIPLE AND QUADRUPLE-PLAY BUNDLING STRATEGIES}

Bundling is the strategy of adopting, competing, and differentiating corporate portfolios in volatile media markets. Bundling strategies add value to different services by inventing economical packages that are convenient to use. As such, bundling can create economies of aggregation for information goods if their marginal costs are very low, even in the absence of network externalities, economies of scale, or economies of scope. Bundling stimulates multi-product media firms to innovate.

The bundling of services is defined as marketing two or more components of the same service together as a package at a special price (Shaw, 2006). A triple-play bundling strategy is the optimum method for leveraging financial gain from the content. This strategy is very common in the software business (e.g., bundle a word processor, a spreadsheet, and a database into a single office suite) and in the cable television industry (e.g., basic cable in the United States and the European Union (EU) generally offers many channels at 1 price). Today, the concept of bundling is dominantly seen as an optimal marketing and management strategy for a multiservice firm 
with access to a client. This strategy profits from cost synergies that include (a) value-adding services and content and (b) price discounts.

A quadruple- and triple-play bundling strategy implies the utilization of multiple services, devices, and technological domains (TV, broadband, telephony, and mobile telephony), but one network, one vendor, and one bill. Broadband has e-merged as the central hub of the bundling trend. There are two main reasons for this: (a) Broadband subscriptions comprise the fastest-growing sector of the global telecoms market with broadband, and (b) it is possible to deliver all the fixed-line elements of a service bundle over the same access technology. These benefits enhance profit; ensure customer loyalty (thereby decreasing customer churn); and increase consumer choices, market shares, and average revenues per user while helping to reduce churn and protect against incursions from new competitors. Competitive pressures and changing consumption habits are encouraging media firms to market bundles of services that include television, telephony, and Internet access (Baranes, 2006). Studies initiated by Whinston (1990) have shown that the profitability of bundling results from economies of scale in the tied market. Other studies (Carbajo, de Meza, \& Seidmann, 1990; Chen, 1997; Seidmann, 1991) have shown that bundling may mitigate competition by inducing more differentiation (Carbajo et al., 1990; Chen, 1997; Seidmann,1991).

The triple-play bundling strategy is most successful when there are economies of scale in production and economies of scope in distribution, marginal costs of bundling are low, production set-up costs are high, customer acquisition costs are high, and consumers appreciate the resulting simplification of the purchase decision and benefit from the joint performance of the combined product. Research by Bakos and Brynjolfsson (2000) found that bundling was particularly effective for digital "information goods" with close to zero marginal cost, and could enable a bundler with an inferior collection of products to drive even superior quality goods out of the market place.

\section{THE ROLE OF NETWORK EXTERNALITIES IN THE MEDIA INDUSTRY AND BUSINESS}

Network externalities were originally introduced in the communications network literature. Before the invention of telecommunications, Internet, and digital media, the effect of network externalities was less visible and dominant. Theoretically, network externalities are described as a mechanism whereby a firm's marginal product of an input is positively affected by other firms' use of the same input (Ongardanunkul, 2003). Network effects arise because of complementarities. In a traditional network, network externalities arise because a typical subscriber can reach more subscribers in a larger network. In addition, it is advisable to point out that by increasing the size of the network, the value of authorized users is increased. At this point, we witness the crea- tion of positive network effects, which raise the 
value received by consumers as mar- kets get larger. As such, the network of competitors with larger market shares will have an advantage over smaller competitors.

The existence of network externalities is the key reason for the importance, growth, and profitability of global media industry in the new, digital, and network economy. Unlike in many other businesses, in the media services industry the benefit from consuming increases with the number of other people consuming (Hoskins et al., 2004). An extra subscriber to the media network brings additional benefits to current subscribers. Similarly, the loss of a subscriber reduces benefits to current subscribers. For example, a telephone is of little value if no one else is using it, of moderate value if only a few of one's potential contacts use it, and indispensable if everyone uses it. Obviously, the value of consuming a certain TV channel by only a few consumers has increased with the number of other subscribers. Economists refer to this phenomenon as network externalities. Accordingly, a product or service possesses network externalities if the utility one derives from it is a positive function of the number of other people who consume it. Most media and communications technologies such as satellite and cable TV, cellular TV, and Internet Protocol (IP) TV are network goods in this sense: They literally constitute a network, and the value of the network depends on the number of persons (or organizations or other entities) connected to it. Historically, indirect network externalities have influenced the outcome of technology competition in many markets, including AM stereo, color television, videocassette recorders, CD players, laser disc players, and personal computers (Ducey and Fratrik, 1989; Farrell and Shapiro, 1992; McGahan et al., 1997). More recently, as analog technologies give way to digital technologies that require new software, indirect network externalities will play an important role in the evolution of a wide range of technology markets (Yoffie, 1996).

Therefore, it is advisable to point out that network effects have attracted significant attention from economists in recent years as they have been driven by a continuous growth of the digital media, Internet and media globalization, a quest for improved efficiency, and cost reduction (Gupta et al., 1999). These paradigm changes that occur in the field of management economy influence value chains to be increasingly reorganized in value networks. The network thus involves corporations, customers, and stakeholders (Peck and Juttner, 2000). At the same time, customers are taking part in global social networks that shape their perceptions and inform their decisions. This is facilitated by increased Internet and mobile communications access.

The result of these different types of associations is called network economyan economy in which the relationships among its members is a product of the information they exchange (Evans and Wurster, 1997). When large international media companies work in a networked economy, they observe lower complexity, better internal communication, flexibility, tailored resource allocation, and high potential for innovation (Johnston and Lawrence 1988). The basic concept of the network economy is that the value of being a part of a network increases as the network size in- 
creases (Lisboa, 2007). Metcalfe's rule states that the value of a network increases proportionally with the square of the number of its members (Cartwright, 2002; Shapiro and Varian, 1998).

In their fundamental study on the network economy, Shapiro and Varian described the rules that guide the dynamics of networks. They argued that it is necessary to achieve a critical mass in the network to grant positive feedback. They also explored the effects that a network is subject to such as network externalities and lock in. Network externalities and critical mass are considered crucial aspects when taking into account the whole network with its multiple stakeholders such as partners, customers, consumers, shareholders, employees, investors, regulatory sectors, governments, and so on (Foss et al., 2004).

However, media management and economics researchers in the mobile-TV and IP TV industries have been slow to respond to the growing importance of network economies and externalities in new product and service adoption. For instance, most new product models in the management science literature assume that new products are autonomous and that the adoption of new products is not affected by the presence or absence of complementary products (Ibid.). These assumptions are being called into question in almost every durable product market in the network economy, where firms rarely act alone to create new products, and products rarely function in isolation (Shapiro and Varian, 1998).

\section{FEATURES OF TWO-SIDED MARKETS}

Digital media services operate platforms that must attract two sides of a market that exhibit network externalities in order to succeed (Wallsten, 2007). This section analyses the main features of two-sided media markets by focusing on the nature of the externaliti- es involved. The author retains the same definition of the two-sided market adopted by both Evans (2004) and Reisinger (2003). A market is said to be two-sided if at any point in time there are:

- two distinct groups of customers;

- the value obtained by one kind of customers increases with the number of the other kind of customers;

- an intermediary is necessary for internalizing the externalities created by one group for the other group (Cortade, 2006).

In his analysis "Antitrust, Two-Sided Markets, and Platform Competition: The Case of the XM-Sirius Merger", Walsten (2007) is right to point out that: "a twosided market is a market that requires a platform for different groups to interact and exhibits network externalities such that more participants from one group will encou-rage additional participants from the other group. Platform providers must figure out how to attract a sufficient number of members of the different groups and 
how to charge them in ways that will cover the costs of building and operating the platform. The difficulty in building a platform for a two-sided market is the presence of network externalities. As explained above, the larger the number of participants from one side, the more incentive there will be for the other side to join, and vice versa".

In addition, the author reinforces the opinion of Anderson and Gabszewicz (2006) who in their article "The media and advertising: a tale of two-sided markets" state that: "the media industry sells a joint product to two different categories of buyers: the medium itself to advertisers, and the medium content to media consumers (readers, $T V$-watchers, web-surfers, etc.)". Media firms thereby operate in two different industries and get their profits from both. The reason stems from the particular market interaction inherent in the commercial television market, which forms a leading example of a "two-sided market" with network externalities. In a two-sided market, two groups interact through an intermediary, or platform, that accounts for the externalities between the groups. In the media context, the platform is the broadcast company (or companies) and the two interacting groups are advertisers and viewers. Advertisers like more viewers to receive their messages (Ibid.).

\section{IMPORTANCE OF MULTIHOMING AND COMPLEMENTORS}

However, there are specific situations in which some agents, in one or both sides of a two-sided market, adopt more than one platform, so that interactions may occur through a series of alternative channels. This particular case is known as the multihoming and can be more easily observed when fixed costs of joining a platform are low or absent. Clearly, the presence of multihoming on one market side influences the degree of competition (Chakravorti and Roson, 2006). The competitive pressure will be stronger wherever a platform can get rid of its competitors, which occurs more easily where singlehoming prevails. As it has already been noticed, the instruments for the competitive fight are lower prices, or larger network volumes on the opposite market side (Ibid.).

Complementors is a term used to describe businesses that directly sell a product (or products) or service (or services) that complement the product or service of another company by adding value to mutual customers; for example, Intel and Microsoft (Pentium processors and Windows), or Microsoft \& McAfee (Microsoft Windows \& McAfee anti-virus).

Moreover, a platform becomes more attractive to consumers as the number of its complementors increases (Carrillo and Tan, 2006). In media industry, platform competition results in a richer structure of interactions: the number of complementors in each platform affects pricing (and therefore profits) of both platforms and all complementors (Ibid.). Naturally, it also affects utility of all consumers. In the twosided markets the value of a platform for one side of the market increases with the 
number of players in the other side of the market that adhere to it. Therefore, the author argues that platforms and complementors always benefit from an increase in the number of complementors in their same platform. Brandenburger and Nalebuff in their influential book 'Co-opetition' point out that the more complements there are and the closer their relationship to the products supplied by the industry the greater the potential profit within the industry (Grant, 2002). Complementors therefore have the ability to raise barriers to entry if incumbent firms have already developed products that are compatible with the complementors' (Haberberg and Rieple, 2008).

\section{ADVANTAGES OF NETWORK EXTERNALITIES ON MEDIA MARKETS (IP TV AND CELLULAR-MOBILE TV)}

Information, media, and communications products and services tend to predominantly define network industries. Accordingly, network economies will necessarily govern the ways that we build and exchange products and services in the information, media, and communications sectors (business and industry). Unlike with traditional cable and satellite TV, the global media market is not saturated with products and services relating to IP TV and cellular-mobile TV. As such, these two types of media are more effectively positioned to utilize the benefits of network externalities.

In addition, the main advantage of IP TV, Internet, and cellular-mobile TV over other media such as newspapers, radio, and TV is that they are not one-way, but rather two-way, mediums of communication. Their content can be efficiently accessed, distributed, as well as customized and repurposed to suit individual consumers' needs and preferences. Because of the fact that it can be efficiently accessed, Internet takes advantage of "locational monopolies," which represents the monopoly from being physically close to the customers (Jansen, 2006).

\section{STRATEGIC AND COMPETITIVE ADVANTAGE OF IPTV}

There are several advantages to IPTV, including Interactivity, Video-on-Demand (VoD), better compression technologies, and triple play efficiencies. Other advantages include content recommendation, better program guides and greater personalization/tailored advertising (Ashun, 2008). Moreover, IPTV's long-term competitive advantage against the cable industry is the ability to segment advertising.

The Targeted Advertising function distributes advertisements to be broadcast to end-users in line with profile and viewing preferences. This function can maximize the effect of an advertisement, more effectively reaching the advertised product's target audience increasing advertising revenue potential. It also benefits end-users as advertisements are more in line with their interests and view preferences. Together 
with VoD and Content Recommendation, Targeted Advertising enhances the value of IPTV as a media.

In terms of the content recommendation it is important to point out that without help, audiences find it challenging to explore and consume the vast amount of content available for viewing and purchase. IPTV's recommendation engine creates a recommendation list from the end-user's profile information such as gender, age group and marital status and viewing histories accumulated in the VoD server. The recommendation server utilizes the "experience, recommend and feedback" paradigm to optimize its recommendations. This platform has the potential to strengthen the linkage between the IPTV service and other product and service lines such as ecommerce. It is advisable to point out that quality, consistency and the safe environment of the IPTV service with the walled garden (main navigation page) at its center should in fact be presented as a core differentiator by IPTV operators. Ease of use is another important factor, both in terms of the consumer being presented with content- on-a-plate rather than having to go out and search for it, and in terms of the actual technology set up in the home.

IPTV provides two-way capabilities, lacked by traditional TV distribution technologies. Interactive television allows for data to be sent back to the TV service provider, which can be used in many ways - such as altering what you are watching (eg: switching camera angles or changing commentators on a sporting event), requesting more information (eg: interactive news, or advertising), or for statistics.

As IPTV supports point-to-point distribution it allows each viewer to view individual broadcast streams (VoD, or Video on Demand). This enables stream control (pause, wind/rewind etc.) and a broad selection of programming. Also, VoD can emulate Digital Video Recorders (DVR), such as TiVo, and may also allow the download of programs to a hard disk for local control. This one-to-one interactive relation- ship/program and content delivery means that a viewer has the capability to pause, rewind or skip through a program under their direct control without affecting other viewers in different locations. The flexibility afforded by this one-toone relationship extends far beyond the control of broadcast programming. Most basic IPTV systems offer compelling interactive services such as on-demand movies and special interest channels. This implies that consumers can watch what they want to watch, when they want to watch it.

In addition, there are at least twelve key components in which IPTV outperforms other rival TV platforms (digital terrestrial, cable or satellite). These segments include:

- Better internet infrastructure;

- Increase in broadband speeds;

- Better compression technology;

- High broadband penetration world-wide; 
- Increased high quality content;

- Positive support from ma-jor telcos;

- Better interactive appli- cations;

- Advances in video-on-demand storage capabilities;

- The development of Secure Conditional Access/DRM solutions for IPTV;

- Next generation, intelligent IPTV set top boxes;

- Better bundling and media diversification strategies;

- Effective application of the "triple play" and a two-sided market structure.

\section{THE MAIN BENEFITS OF MOBILE TV}

The main benefits that will improve the potential growth of mobile TV industry include: strong brand infrastructure, targeted services, changing market landscape, Upgrading of 3.9G/4G networks (Korhonen, 2009), new content formats, targeted advertising, personalized content programming and presentation, as well as improved customer relations.

In addition, Mobile TV enables much more personalized and enriched communications between end users and service providers which represents a step change in terms of marketing effectiveness. This enables stakeholders to communicate with their audience on a more individual level.

\subsection{Benefits for End Users}

Mobile TV allows end users to consume TV or radio in any place at any time. As such, end users are no longer restricted to their homes to access their favorite TV programmes. They could buy content or products without being at home or in a shopping mall, deciding to buy now and consume later. This richer and more diverse content or information enables better time management, even when they are away from the home or office. They will benefit from "long tail" economics through access to niche content delivered over an almost limitless range of TV channels compared with analogue TV and radio broadcast services.

\subsection{Benefits for Mobile Operators}

The main benefit for mobile TV operators is the concept of an identifiable and addressable user that is inherent to a mobile network. Such a user is authenticated by default, has ubiquitous access and can conduct transactions over networks with acceptable latencies via mobile TV click-through requests. Furthermore, the user can connect directly to mobile web services, provided either by the mobile operator or other service providers, potentially fully synchronized with on-air TV programmes. 
The opportunities for mobile operators to drive the interactive TV market are substantially larger as a result of this greater personalization and faster user interaction. The VTT study of mobile television clearly indicated that mobile device is in many respects, better suited to interactive applications than normal television (Sodergard, 2003). In addition, as mobile operators have recognized service portfolios through their mobile ser- vice delivery platforms they can act as a service provider for interactive services, as a service distributor or can manage hosted products for 3rd parties (such as commerci- als and advertising).

\subsection{Benefits for Broadcast Operators}

Prior to intensive and expanding global competition in the field of media and telecommunications, broadcasters are constantly looking for innovative content formats and services to deliver new opportunities for revenue and long term customer retention. Mobile TV provides broadcasters with opportunities for personal targeting - Mobile TV click-through concepts. This new opportunity opens up the potential of cooperation between operators and broadcasters based on appropriate ecosystems and business models. Mobile TV will aid broadcasters to strengthen their relations with specific target segments such as young users and early adopters of web-based technologies by leveraging their existing brands through new delivery channels and content formats relations (Mobile TV UMTSF/GSMA Joint Work Group, ...).

\subsection{Benefits for Other Industries}

Mobile TV opens up new opportunities for many industries either 'adjacent to' or 'distant from' mobile multimedia (Ibid.). Manufacturers and suppliers of handsets, platforms, broadcast systems, content editing and distribution systems, customer relations centers, billing and IT systems, advertising agencies, IPR and rights owners could all benefit from wider distribution of their products and services. Rights owners are pushing for greater control over the distribution of their creative output. The return path of mobile TV could help by introducing DRM.

Local channels or shops could benefit from more effective broadcast advertising using the personalization or the regional broadcasting capability of mobile TV. However, advertising markets are based on audience and cannot by themselves justify the investment in new broadcasting networks or systems. Without an audience, advertisers are not interested.

'Adjacent' industries include the traditional TV broadcasters, content creators and content aggregators. These industries will benefit greatly from the wider introduction of mobile TV, although achieving the required mass audience will take some time. New cooperation opportunities will arise between stakeholders such as diffe- 
rent multimedia providers, broadcasters, mobile operators and IPTV service providers. Collaboration between these individual parties will open up opportunities for new mobile broadcast services and strengthen the interaction between user and service provider as well as between service providers themselves. Some 'distant' industries currently not participating in the traditional TV value chain will grab the new opportunities offered by mobile TV. Such companies might specialize in electronic service guides for mobile TV or be 'TV-commerce companies' leveraging the click-through capabilities of the mobile TV ecosystem. Special mobile TV related web-based companies will be just one click away from TV programmes shown on a handset. In the more 'distant' industries, the advertising value chain from creative through to production will also benefit from the fundamental differences between the mobile community needs and the traditional time-based and homebound captive terrestrial TV market. This will increase the interactivity and impulse 'buy now' opportunities closely linked to the more interesting segmentation profiles of mobile users. Further 'distant' industry opportunities include opportunities for players in the nascent mobile commerce market through the creation and development of key partnerships or financial outsourcing arrangements. These players will benefit from the provision of mobile shopping TV, combining TV with mobile premium content offers such as the downlo- ad of additional content, ring-tones, logos, trailers or clips (Ibid.).

\section{BARRIERS TO THE USE OF MOBILE TV}

The main barriers facing a more rapid development of the mobile TV are: Conflicting broadcast mobile TV standards: DVB-H, DMB, MediaFLO, 1seg, MBMS, TDtv, CMMB, TMMB, DMB-T/H, CDMB, CMB and ATSC-M/H.

- Battery life

- Image quality

- Lack of content

- Consumer disinterest

- Government regulation

\subsection{Conflicting broadcast mobile TV standards}

The absence of single, universal and standardized digital TV broadcast format and bandwidth for Mobile TV causes inefficient interoperability between devices, creating a limited market and application of services development. Presently there are four major DTV handset standards in use: ISDB-T (Japan); DVB-H (Europe and US), DMBX (Korea) and MediaFLO (US). The clear standards winners will be those DTV handset standards that are open and non-propriety. 


\subsection{Battery life}

The most important feature to realize about the difference between mobile TV and digital TV is that with digital TV at home, an end user got an unlimited power supply, which is quite handy. But TV screens are notoriously power hungry. In mobile versions the backlight and speaker will need to be on throughout the programme. Watching Mobile TV is a significant drain for the mobile phone's battery. Most of current tuners for digital TV sets predominantly do not offer the low battery consumption required to give users the battery life they expect in a mobile phone (Texas Instruments White Paper, 2005). The additional processing power needed for live broadcast TV will also affect power consumption and must be taken into account. However, battery life is presently less of an issue in the home context where the device can either be docked in a charging cradle or connected to the nearest available power socket (Chipchase et al., 2005).

\subsection{Image Quality}

Although the image resolution is a central concern for all actors involved in the field of mobile TV (device manufacturers, users, content distributors and content producers), the image quality on Mobile TV is still not comparable to traditional TV set (Knoche et al., 2006). Wireless carriers hope that the faster 4G network will improve image quality and lead to more content-such as movies, news clips, realtime sports, mini-soap operas and full-length TV programs-thus driving demand. Video quality depends on several factors, including the quality of the phone and the network that it is sent over. Presently, on a $3 \mathrm{G}$ cellular network, video runs at 15 frames per second, while regular broadcast television runs at 30 frames per second.

The phone itself can also determine the quality of the video. The more processing power available in the device, the better the video will look. However, where $\mathrm{TV}$ images are concerned, the general studies conducted suggest that 'the bigger is the better'. This clearly presents a challenge to mobile TV where there is a trade-off between the screen size and the portability of the device (Ibid.).

\section{GLOBAL TRENDS IN MOBILE TV - FURTHER RESEARCH}

In order to fully leverage the concepts of dual markets and network externalities, mobile TV and IPTV industry leaders might consider option of converging digitally their content production and services. The model of digital convergence between Mobile TV and IPTV business should be dominantly based on the following factors: convergence of networking interface and interoperability path, integration of services and re-purposing of content distribution, timely facilitation of content transfer from mobile TV to IPTV, common program production and formatting, 
cross-platform pro- file access and billing, cross-platform content access, PC access to IPTV and MTV (Mobile TV) and Transferring program from IPTV to mobile TV.

\section{CONCLUDING REMARKS}

In this paper the author proposes a new paradigm shift in digital media economy by adopting the role of the economies of aggregation. As such, the author argues that in order to position effectively global media industry and business in highly competitive and volatile market, it is necessary for international corporations to provide a holistic response that regards economics as a set of mutually interactive aggregate segments. As such, it is advisable to adopt innovative approach in emphasizing the economies of aggregation that feature the Triple- and Quadruple-Play Bundling Strategies, Two-Sided markets, Complementors and Network Externalities.

The author empirically proves the validity for IPTV and Mobile TV market growth by calculating the projected number of worldwide users from 2009 to 2015 based on the analysis of nineteen leading international research and consulting agencies (In Stat Research, Datamonitor Research, Inofonetics Research, RNCOS, Informa Telecoms and Media, Juniper Research, McKinsey Research, etc). The figures show an increase of Mobile TV subscribers from 2009 to 2015 for approximately $242 \%$ ( 78.5 to 190 millions). On the other hand, the research shows an increase of IPTV subscribers from 2009 to 2013 for $202 \%$ (42.2 to 85.5 millions).

In addition, the author argues that the digital switchover, the untapped market of new broadband and mobile/cellular technologies, combination of near ubiquitous broadband access, increasing digital convergence, lower equipment costs and home networking, competitive pressure among cable, satellite and telecom operators,consumer familiarity with a 'pull medium' - cellular phone and the Internet, all point to a rapidly developing market for both IPTV and Mobile TV.

Accordingly, the network externalities and two-sided markets provide international media companies with the opportunity to deliver bundled triple play services with a common infrastructure and a common user experience in order to maximize revenue and maintain customer loyalty. The effect of Two-Sided markets and network externalities will help media companies to attain the economies of scale needed to le- verage the creative content and technology.

In addition, the digital convergence of mobile TV and IPTV will extend positive effects of network externalities and provide international media companies with valuable models of content re-purposing and related media diversification. This is particularly true if we take into consideration that only $1.8 \%$ of all mobile phone users worldwide that are presently estimated at 3.3 billion are Mobile TV subscribers. On the other hand, only $2.2 \%$ of all TV users worldwide (currently estimated at 1 billion) are IPTV subscribers. 


\section{BIBLIOGRAPHY}

Anderson, S. P., Gabszewicz, J. J. (2006), „The media and advertising: a tale of twosided markets in Victor Ginsburgh and David Throsby“", Handbook of Cultural E- conomics,Elsevier Science, North-Holland Publishing company, Chapter 18, pp. 567-614.

Ashun, P. (2008), IPTV Overview. Future Media \& Technology: Keeping the BBC relevant in the digital world, $\mathrm{BBC}$, Presentation.

Bakos, Y., Brynjolfsson, E. (2000), „Bundling and competition of information goods on the Internet", Marketing Science, Vol. 19, pp. 63-82.

Baranes, E. (2006), „Bundling and collusion in communications markets“, Working Paper, No. 06-17, NET Institute.

Barrett, C. B., Yang, Y. N. (2001), „Rational incompatibility with international product standards", Journal of International Economics, Vol. 54, pp. 171-191.

Carbajo, J., de Meza, D., Seidmann, D. J. (1990), „A strategic motivation for commodity bundling“, Journal of Industrial Economics, Vol. 38, pp. 283-298.

Carrillo, J. D., Tan, G. (2006), „Platform Competition: The Role of Multi-homing and Complementors", Working Paper, \#06-30 October, The Networks, Electronic Commerce, and Telecommunications ("NET") Institute.

Cartwright, P. A. (2002), „Only converge: Networks and connec-tivity in the information economy", Business Strategy Review, Vol. 13, No. 2, pp. 59-64.

Chakravorti, S. Roson, R. (2006), „Two-Sided Markets: The Case Payment Networks", Review of Network Economics, Vol. 5, Issue 1, pp. 118-143.

Chen, Y. (1997), „Equilibrium product bundling“, Journal of Business, pp. 85-103.

Chipchase, J., Yanqing, C., Jung. Y. (2005), „Personal Television: A Qualitative Study of Mobile TV Users in South Korea“, Research paper sponsored by The Nokia Research Center, Mobile HCI Group. http://research .nokia.com/people/ jan_chipchase/PersonalTV_MobileTV.pdf

Compaine, B., Gomery, D. (2000), Who owns the media?, Lawrence Erlbaum Associates, Inc., Mahwah, New Jork.

Cortade, T. A. (2006), „A Strategic Guide on Two-Sided Markets Applied to the ISP Market", MPRA Paper, No. 61 (2), pp. 193-208.

Ducey, R. V., Fratrik, M. R. (1989), „Broadcasting industry response to new technologies“, Journal of Media Economics, Vol. 2, pp. 67-86.

Economides, N. (1996), „The economics of networks“, International Journal of Industrial Organization, Vol. 14, pp. 673-699.

Economides, N. (1996q), „Network externalities, complementarities, and invitations to enter", European Journal of Political Economy, Vol. 12, pp. 211-233.

Evans D. S., (2004), "The antitrust economics of two-sided markets", Yale Journal on Regulation, Vol. 2, pp. 325-382.

Evans, P. B., Wurster, T. S. (1997), „Strategy and the new economics of information“, Harvard Business Review, Vol. 75, No. 5, pp. 70-82. 
Farrell, J., Shapiro, C. (1992), „Standard setting in high-definition television“ in M. N. Baily \& C. Winston (Eds.), Brookings papers on economic activity, Brookings Institute, Washington, DC.

Foss, N. J., Kristensen, T., Wilke, R. (2004), „Corporate communication in the emerging network economy: A provider of common knowledge", Corporate Coтmunications: An International Journal, Vol. 9, pp. 43-49.

Grant, R. M., (2002), Contemporary Strategy Analysis, Fifth Ed., Wiley, John \& Sons, Incorporated.

Grant, R. M. (2008), Contemporary Strategy Analysis, Blackwell, Oxford, England. Gupta, S., Jain, D. C., Sawhney, M. S. (1999), „Modeling the evolution of markets with indirect network externalities: An application to digital television", Marketing Science, Vol. 18, p. 396-416.

Haberberg, A., Rieple, A. (2008), Strategic Management, Oxford University Press, Oxford.

Harris, C., Harris, C.M. (2002), Hyperinnovation: Multidimensional Enterprise in the Connected Economy, Palgrave Macmillan.

Hoskins, C., McFadyen, S., Finn, A. (2004), Media economics: Applying economics to new and traditional media, Sage, Beverly Hills.

Jansen, D.W. (2006), The new economy and beyond, Edward Elgar Publishing, Incorporated, Cheltenham, England.

Johnston, R., Lawrence, P. R. (1988), „Beyond vertical integration - The rise of the value adding partnership“, Harvard Business Review, Vol. 66, No. 4, pp. 94 101.

Katz, M. L., Shapiro, C. (1994), „Systems competition and network effects“, Journal of Economic Perspectives, Vol. 8, No. 2, pp. 93-115.

Kikuchi, T., Kobayashi, C. (2007), „Network effects and the impact of trade liberalization", Economics Bulletin, Vol. 6, No. 4, pp. 1-7.

Knoche, H., McCarthy, J., Sasse, A. (2006), „A close-up on Mobile TV: The effect of low resolutions on shot types" in Proceedings of The 4th European Conference on Interactive Television, ELTRUN-AUEB, Greece, pp. 359-367.

Korhonen, J. (2009), Mobile TV - A New battle of Standards, Cantlab Wireless Limited, Cambridge, U.K.

Le Bas, C., Latham, W. R. (2005), The Economics of Persistent Innovation, SpringerVerlag New York, LLC.

Lisboa, J. (2007), Network marketing, Unpublished doctoral thesis, Cranfield School of Management. Bedford, Bedfordshire, United Kingdom.

McGahan, A., Vadasz, L. L., Yoffie, D. B. (1997), „Creating value and setting standards: The lessons of consumer electronics for personal digital assistants“, in D. B. Yoffie (Ed.), Competing in the age of digital convergence, HBS Press, Boston.

McMeekin, A., Wals, V., Green, K., Tomlinson. M. (2002), Innovation By Demand: An Interdisciplinary Approach to the Study of Demand and Its Role in Innovation, Manchester University Press. 
Mobile TV UMTSF/GSMA Joint Work Group, Final White Paper "Mobile TV: The Groundbreaking Dimension", Retrieved January 15, 2007, http://www.umtsforum.org/servlet/dycon/ztumts/umts/Live/en/umts/

MultiMedia_PDFs_Papers_joint- mobile-tv-group-white-paper

Ongardanunkul, $\overline{\mathrm{P}}$. (2003), Essays on network externalities: Theoretical and empirical analyses, Unpublished doctoral dissertation, Graduate School of Arts and Sciences, Department of Economics, Boston College.

Peck, H., Juttner, U. (2000), „Strategy and relationships: Defining the interface in supply chain contexts", International Journal of Logistics Management, Vol. 11, No. 2, pp. 33-44.

Reisinger, M. (2003), "Two-Sided-Markets with Negative Externalities," Universi-ty of Munich, Mimeo.

Seidmann D. J. (1991), „Bundling as a facilitating device: A reinterpretation of leverage theory“, Economica, Vol. 58, pp. 491-499.

Shapiro, C., Varian, H. R. (1998), Information rules: A strategic guide to the network economy, Harvard Business School Press Books, Cambridge, MA.

Shaw, M. (2006), Commerce and the digital economy Sharpe, Armonk, New York.

Shy, O. (2001), The economics of network industries, Cambridge University Press, New York.

Sodergard, C. (203), Mobile television - technology and user experiences Report on the Mobile - TV project (Rep. No. P506) VTT Information Technology.

Texas Instruments White Paper (2005), Technology for Innovators: Digital broadcast TV - Coming soon to a mobile phone near you, http://focus.ti.com/pdfs/ wtbu/ti_digitaltvforhandsets.pdf

Trauffler, G., Tschirky, H.P. (2007), Sustained Innovation Management: Assimilating Radical and Incremental Innovation Management, Palgrave Macmillan.

Vanhaverbeke, W., West, J., Chesbrough, H.J. (2006), Open Innovation: Researching a New Paradigm, Oxford University Press, USA.

Vizjak, A., Ringlstetter, M. (2003), Media management: Leveraging content for profitable growth, Springer, New York.

Whinston, M. D. (1990), „Tying, foreclosure and exclusion“, American Economic Review, Vol. 80, pp. 837-859.

Yoffie, D. B. (1996), „Competing in the age of digital convergence“, California Management Review, Vol. 38, No. 4, pp. 31-53.

Wallsten, S. A. (2007), Two-Sided Markets, and Platform Competition: The Case of the XM-Sirius Merger, The Progress \& Freedom Foundation, Commentary. Analysis. 